International Journal of Linguistics, Literature and Translation

ISSN: 2617-0299 (Online); ISSN: 2708-0099 (Print)

DOI: $10.32996 / \mathrm{ijllt}$

Journal Homepage: www.al-kindipublisher.com/index.php/ijltt

\title{
A Pragmatic Analysis of Mitigation in the New Testament and Prophetic Traditions
}

\author{
Riyadh Tariq Kadhim Al-Ameedi ${ }^{8}$ (D) Adawiaya Sattar Ablood ${ }^{2} \mathbf{8}$ (D) \\ ${ }^{1}$ Department of English, College of Education for Human Sciences, University of Babylon, Babylon, Iraq \\ ${ }^{2}$ Thi-Qar Directorate of Education, Iraq \\ $\triangle$ Corresponding Author: Riyadh Tariq Kadhim Al-Ameedi, E-mail: riyadh.tareq@uobabylon.edu.iq
}

ARTICLE INFORMATION ABSTRACT

Received: June 09, 2021

Accepted: July 15, 2021

Volume: 4

Issue: 7

DOI: 10.32996/ijlt.2021.4.7.17

\section{KEYWORDS}

Pragmatic analysis, speech acts, politeness, deixis, conversational strategies, New Testament, Prophetic Traditions
This paper attempts to investigate mitigation in biblical verses and prophetic traditions from a pragmatic perspective. This study tries to answer the following question: what are the most common pragmatic theories by which this phenomenon is conveyed by the speaker and understood by the listener. Accordingly, it tries to achieve the following aims: 1) specifying the most prominent categories of speech acts employed in such texts; 2 ) delineating the politeness strategies exploited in this discourse; 3 ) identifying the deictic expressions and pragmatic - conversational strategies utilized in both texts, It is hypothesized that 1) biblical verses and prophetic traditions show variations in the use of directive speech acts; 2) both positive and negative politeness strategies are employed in religious discourse ;3) non-specific reference and second person plural as deictic expressions are supposed to be used widely in this discourse;4) hinting strategy is employed highly in religious discourse because it indicates indirectness. An eclectic model is developed which utilizes Searle's (1969) model of speech acts and Brown \& Levinson's (1987) model of politeness. The data of analysis are limited to three biblical texts taken from the New Testament and three prophetic traditions. Findings of the analysis reveal that the first and second hypotheses are fully validated whereas the third and fourth ones are partially invalidated in that non-specific reference pronouns such as 'one' is not used in biblical texts and the hinting strategy is not the most prominent strategy in biblical texts.

\section{Mitigation: Theoretical Underpinnings}

The concept of mitigation is related to adjustments, which are usually carried out through modulations in intensity resulting in stylistic oscillations between weakening and reinforcing choices (Caffi, 2007:15). The concept of adjustments and modulations is the core of what can be called the rhetoric of every interaction which is related to metapragmatic awareness, i.e. to the knowledge of both language and the world and the ability to be appropriate to a given communicative situation. Historically, the concept of mitigation was handled under the rubric of ' adaptation at the beginning of the twentieth century both in sociology and linguistics. Charles Bally developed his stylistics of language around the central idea of 'adaptation ' that is adaptation to the situation. Bally (1970: 297) says that "speakers boost or weaken their discourse in order to reach their interactional goals". The broader sense of adjustments and modulation to the situation is to adapt to changing circumstances, including different speakers and listeners stances, time, places, persons addressed or referred to, is precisely the main function of mitigation.

Fraser (1980:341-350) defines mitigation as " the modification of a speech act: the reduction of certain unwelcome effects which a speech act has on the hearer ". In a pedagogical framework, Edmondson (1981:115) proposes in his theoretical model many moves

\section{K C AL-KINDI CENTER $R$ DFOR RESEARCH AND} Your gateway to world-class research

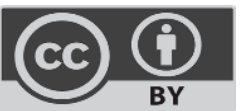

Published by Al-Kindi Center for Research and Development, London, United Kingdom. Copyright (c) the author(s). This open access article is distributed under a Creative Commons Attribution (CC-BY) 4.0 license 
that are conceptually related to mitigation and he describes them as ' hearer-supportive ' that fall into three types: grounders, expanders, and disarmers.

Concerning the commitment to the truth value of the proposition, Prince et al. (1982:86) distinguish two types of modifications: 'approximators' which are conceptually related to hedges, and 'shields' which are defined as mitigators that do not refer to any particular person but the utterance source is referred to in terms of impersonalization mechanism. Some notions, overtly or covertly, are related to mitigation; among which is Goffman's s(1967) notion of ' face ' which has the idea of mitigation as its center. The strategies of both positive and negative politeness can be read as mitigating strategies. The maxims of politeness in Leech's (1983:132) model of discourse focus on the devices that minimize the impact of a face-threatening act.

In the same vein, Brown and Levinson's (1987:42) model of politeness treats mitigation as a synonym of politeness. Two notions of face: positive and negative face of both the speaker and the hearer are included in this model in which politeness is viewed as face-saving management. According to the motivation of mitigation, Fraser (1980:344) differentiates between two types: selfserving and altruistic. The former considers the unwelcome effect such as hurt, anger, opposition, or whatever the hearer would hold towards the speaker. The latter type considers the speaker's intention to soften the effect the utterance has directly on the hearer, for example, mitigating the effect of alarm, fear, or pain. Caffi (2007:217) distinguishes between illocutionary mitigation which is related to acts whose illocutionary force is inherently negative for the hearer, that is inherently face -threatening to the hearer, such as criticisms, reproach, cursing; and propositional one in which the propositional content is inherently negative for the hearer, for example, the mitigation of bad news.

\section{Pragmatic Means}

\subsection{Speech Acts}

The concept of 'speech act' is an important cornerstone in a pragmatic account of language by which the communicative use of language as an intentional human action is perceived evidently. Searle et al.(1980:vii) state that the notion of speech acts starts with the assumption that " the minimal unit of human communication is not a sentence or other expression, but rather the performance of certain kinds of acts, such as making statements, asking questions, giving orders, describing, explaining, apologizing, thanking, congratulating, etc".

Speech act theory(SAT) was introduced by Austin (1962) in his book ' How to Do Things with Words ' to describe an essential aspect of pragmatic account of language that represents the connections between utterances, the speaker's intention, and the context. This theory focuses on the utterance's meaning (intention), not the sentence's meaning (literal). Searle (1969) develops a taxonomy in which he uses ' illocutionary acts' instead of 'speech acts'. He classifies illocutionary acts into five types: representatives, directives, commissives, expressive, and declarative.

According to Van Dijk(1977) as cited in Al-hindawi and Al -khazaali (2011:7), various speech act relations, in which an auxiliary speech act and one of the main components act in compound speech acts, are investigated. Eight auxiliary speech acts are indicated: justification, explanation, addition, conclusion, contradiction, explication, correction, and condition. These speech acts are called auxiliary because their role is conveying miner parts of the communicative message of the major SAs.

In Arabic, the theory of SAs is equivalent to the concept of constative (Al-Khabar ) and performative (Al- Insha'a ). These two concepts have been approached variously by three types of scholars: grammarians, rhetoricians, and jurisprudents.

Rhetorically, السكاكي (1983:164) defines constative as " the speech which probably be true or false", so if the constative is identical to its external reality (the world) then it will inevitably be true. On the other hand, if it does not fit its reality, it will be false.

\subsection{Politeness}

In accordance with Fraser's (1980:344) view that " mitigation occurs only if the speaker is also being polite ", the data will be analyzed in terms of Brown and Levinson's (1987) politeness strategies that include two types: positive and negative strategies.

1- Positive Politeness strategies are practiced to save the addressee's positive face -these strategies include:

-Claim Common Ground: In this strategy both speaker and hearer belong to the same set of wants, values, and goals that should be thought of as desirable to make the relationship friendly.

- Intensify Interest to Hearer: This strategy is concerned with the speaker's interest to communicate that the hearer's wants, interests are to be intensified and involved into the conversation, e.g.

-What a fantastic garden - you have!

-Use -in -Group Identity Makers: By such a strategy, the speaker can put the hearer in the same group to which the speaker belongs as the inclusive pronoun 'we' and 'us', e.g.

Page | 155 
- Let's get on with dinner.

2- Negative Politeness Strategies: These strategies show the speaker's care and respect to the hearer's negative face by the following strategies:

- Minimizing the Imposition: By the expressions that are employed in this strategy, the speaker attempts to minimize the potential threat to the addresses, for example:

-Could I borrow a tiny wee bit of paper. (Brown and Levinson, 1987:179).

- Be optimistic: In this strategy, the speaker wants the hearer to do something by expressing this want in terms of using certain words (e, g. possibl) or negative- interrogative or conditional constructions by which the speaker's want becomes easier for the addressee to refuse or accept, consequently, there is less risk of loss of face (ibid:180), e.g.

-You'll lend me your lawnmower for the weekend, I hope.

In Arabic, Linguistic politeness is seen as a representation of pragmatic competence which is embodied in the growth of communication strategies. The term ' face' is associated with the matters of politeness to express different meanings which are common in our everyday communication, such as ' حفظ ماء الوجه ' (saving face) to indicate face-saving; ' (losing his face ) to refer that this person humiliated himself and other uses to indicate the meanings of ' respect' ' honor', ' shame', and dignity (Boubendir, 2012: 54-5).نسان (2006:343) connects the Arabic respectful behavior with the cultural concept ' mujamela' which he describes as "the active, ritual realization of differential perceptions of 'superiority' and 'inferiority 'in interaction".

\subsection{Deixis}

The analysis of the data will involve the perlocutionary effects caused by the deictic categories expressing person deixis. Person deixis that has mitigating effects are the first-person singular ' I' and plural ' we', the second person, the third person, and the indefinite pronoun ' one' which has no specific reference. Both of the first person singular and plural indicate jointness and solidarity which imply that the responsibility of performing instructions and moral teaching is shared by the speaker and the hearer. consequently, it protects the hearer's positive face. Such deictic expressions encode specific aspects of the speech events and cannot be interpreted unless contextual parameters are taken into account (Marmaridou, 2000: 65).

The notion of deixis is not discussed in one comprehensive topic by Arab linguists and grammarians. It is studied in different places like pronouns, demonstratives, adverbs, and particles, and verbs الجامي (2003:76) defines the pronoun as what is put for a speaker, an addressee or an absent that is mentioned in a word or in meaning previously.

\subsection{Conversational Strategies}

Conversational strategies are defined in pragmatic studies as a set of ways and methods that communicate the intentions of the speaker to the listener. There are many theories that have dealt with these strategies, especially the hinting strategies, among which is Grice's (1975) conversational implicature. This theory has a great role in defining the features of hinting strategy by formulating certain logical rules about which there is an agreement between the speaker and the hearer to communicate smoothly and any violation of these rules will imply an implicature (intended meaning) which is understood by inference on the hearer's part. Searle (1976) deals with such strategies within his theory of illocutionary acts when he divides these acts into direct and indirect. الشهري (2004: 86) states that these strategies are classified according to three criteria :

1) Social criterion which is concerned with the kind of relationship between the addresser and the addressee. Two strategies are stemmed from this criterion: Solidarity and directive strategies

2) The form of the discourse. This criterion is related to the form of the linguistic discourse that indicates the addresser's intention. The hinting strategy is derived from this criterion.

3) The aim: The argumentative or persuasive strategy emerges from this strategy.

Hinting is a strategy by which the addresser expresses the intention in a way that contradicts the literal meaning of the speech to accomplish with it more than what he says through employing the elements of context (تغزاوي), 2014:202). The fertile and broad field of the hinting strategy is rhetoric especially علم البيان(the science of eloquence) which involves metaphor, simile and metonymy, and deviation in structures, such as proposing and postposing.

One of the aims of argumentative strategy is persuading which is one of the purposes that the addresser seeks to achieve in his speech. Convincing is the process of bringing about a change or determination of situation, belief, or behavior which is a result reached by the addresser by using different linguistic tools, such as repetition, justification and reasoning words, like التعليل 
(for), لكي,فاء السببية (to) ...etc. (الجيلالية, 2012:20) , and by rhetorical strategies like التقسيم او التفريع) (division and branching) والتمثيل الاستعارة) الأستجواب (metaphor and analogy) الكناية (questioning), and (metonymy), 2013:120).

Significantly, intertextuality, especially religious one, contributes to discourse construction and elevating its expressive level through influencing the recipient, awakening his feelings, and causing the internal change intended by the speaker. This is what is called 'التعليم بالدليل' (teaching by evidence), so the speech becomes argumentative that help the addressee to gain a clear truth which reassures his heart and relieve him (المالكيم, 1987:296).

\section{Methodology and Data Analysis}

\subsection{The Model of the Study}

An eclectic model will be adapted to analyze the present data. It contains Searle's (1969) model of the classification of SAs, Brown and Levinson's (1987) model of politeness, and الشهري)(2004) model of conversational strategies.

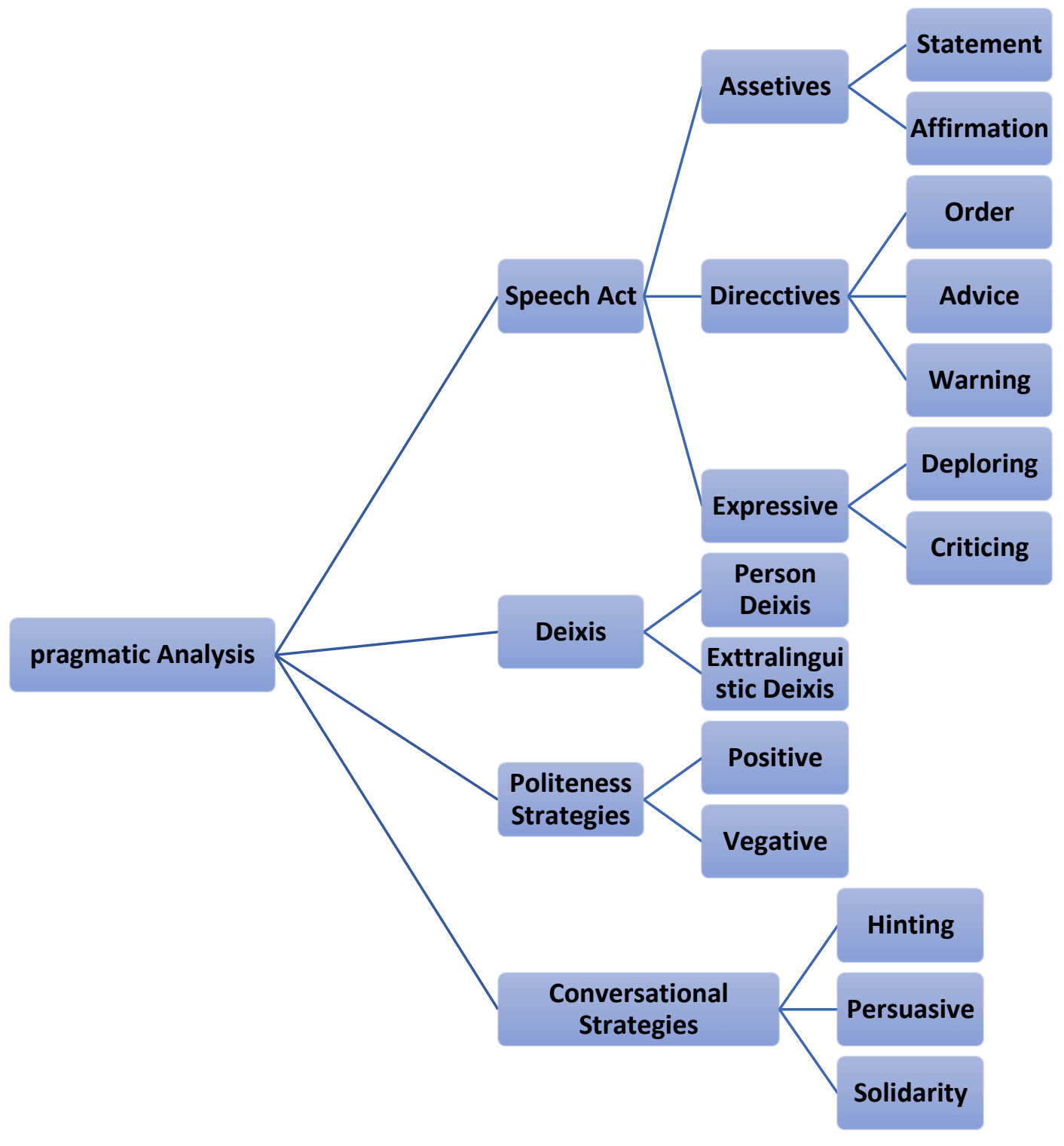

Figure (1) The Model of Analysis 


\subsection{Data Analysis}

\subsubsection{Pragmatic Analysis of Mitigation in Biblical Texts}

Text (1)

When he saw the crowds, he went up the mountain. After he sat down his disciples came to him. Then he began to teach them by saying:

" Ask and it will be given to you; seek and you will find; knock and the door will be opened for you. For everyone who asks receives, and the one who seeks finds, and to the one who knocks the door will be opened. Is there anyone among you who, if his son asks for bread, will give him a stone ? or if he asks for a fish, will give him a snake? If you then, although you are evil, know how to give good gifts to your children, how much more will your Father in heaven give good gifts to those who ask Him ?" (Matthew, 7:7-11).

Overtly, the text shows a speech act of ' ordering' since it begins with the sentences that involve the imperative verbs: ' ask ', seek', and ' knock', but they depart its true function as ' an order' to carry an implicit illocutionary force of ' advice ' with no obligation. Thus, it implicitly urges the addressee to respond and he is not obliged to adhere to the advice. Jesus Christ (Jxtell) advises his disciples to be in a continuous relationship with God ( (fen ) through ' praying ' and do not be despondent. The three speech acts of advice are followed by an assertive speech act, For everyone who asks receives....to justify the preceding acts. The words ' son ' and ' give ', ' find ', and ' Father ' can be labeled as ' lexical hedges whose function is dilution, that is, ' accelerators of intimacy ' that decrease the psychological distance between the preacher and the advised one. Thus, such lexemes represent the solidarity

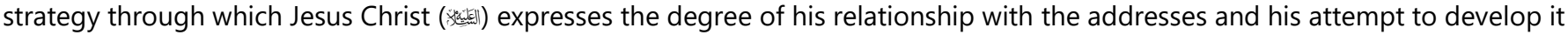
by eliminating the differences between them. Importantly, these lexemes reflect his understanding of the audience's needs and trying to get closer to them, so they are one realization of positive politeness. He(watell) uses the second person plural 'you' which is implied in the verbs: 'ask', 'seek', 'knock' to give a sense of generality. Interestingly, he (xitul) uses another conversational strategy that is represented by questioning as a way to convince the crowd to be optimistic.

Table (1) Pragmatic Analysis of Text (1)

\begin{tabular}{|c|c|c|c|}
\hline \multicolumn{4}{|c|}{ Pragmatic Analysis } \\
\hline Speech Act & $\begin{array}{l}\text { Strategy } \\
\text { Type } \\
\text { Intended Acts } \\
\text { Strategy } \\
\text { Type }\end{array}$ & $\begin{array}{l}\text { Indirect } \\
\text { Order } \\
\text { Advice } \\
\text { Direct } \\
\text { Assertive }\end{array}$ & 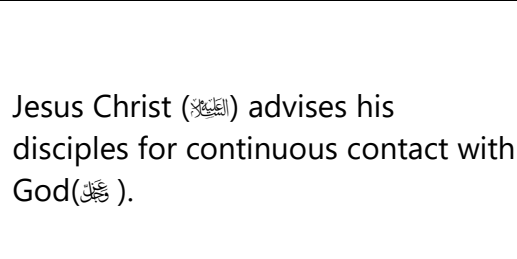 \\
\hline Diexis & Person & Second Person Plural & \\
\hline $\begin{array}{l}\text { Politeness } \\
\text { Strategy }\end{array}$ & $\begin{array}{l}\text { Positive } \\
\text { Negative }\end{array}$ & $\begin{array}{l}\text { Intensify Interest to Hearer } \\
\text { Be Optimistic }\end{array}$ & \\
\hline $\begin{array}{l}\text { Conversational } \\
\text { Strategy }\end{array}$ & $\begin{array}{l}\text { Solidarity } \\
\text { Persuasive }\end{array}$ & Questioning & \\
\hline
\end{tabular}

Text ( 2)

At that time Jesus went through the grainfields on a Sabbath. His disciples came to him and he began to teach them and said:

" Make a tree good and its fruit will be good or make a tree bad and its fruit will be bad, for a tree is known by its fruit, for the mouth speaks from what fills the heart. The good person brings good things out of his good treasury, and the evil person brings evil things out of his evil treasury".(Matthew, 12: 33-35).

From a pragmatic point of view, this text presents an ' ordering speech act ' since it begins with the imperative verb ' make ', but implicitly it implies an indirect illocutionary force of ' advice '. It can be read as 'I advise you to be pure-hearted and to get rid of 
evil intentions that spoil your hearts '. To mitigate the negative impact of the imposition, Christ (yatel) makes a 'a simile' relationship

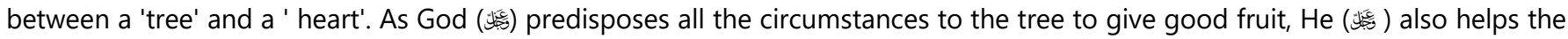
human to be good by providing him with all ' senses ' that are considered as resources of ' spiritual food '. Such a gift is endowed to all humans, so they have the same values. Thus, it gives a hint to claiming a common ground that saves the hearer's positive face. What is needed is to feed our senses with valuable information to fill our hearts with good treasures that lead to good speech. In this sense, Christ ( (xt) wants to say that the opportunity is available for everyone to change, i.e., to be a good man. The following assertive speech acts function as justification since they give the reason for preceding acts. Therefore they can be considered as a persuasive strategy. The second person plural 'you' which is implied in the verb 'make' is used to save the hearers' negative face because it makes no specific reference

Table (2) Pragmatic Analysis of Text (2)

\begin{tabular}{|c|c|c|c|}
\hline \multicolumn{4}{|c|}{ Pragmatic Analysis } \\
\hline Speech Act & $\begin{array}{l}\text { Strategy } \\
\text { Type } \\
\text { Intended Acts } \\
\\
\text { Strategy } \\
\text { Type }\end{array}$ & $\begin{array}{l}\text { Indirect } \\
\text { Order } \\
\text { Advice } \\
\\
\text { Direct } \\
\text { Assertive }\end{array}$ & $\begin{array}{l}\text { Jesus Christ ( } \\
\text { advises the crowd to be } \\
\text { pure-hearted to } \\
\text { produce } \\
\text { good speech. }\end{array}$ \\
\hline Diexis & Person & Second Person Plural & \\
\hline Politeness Strategy & $\begin{array}{l}\text { Positive } \\
\text { Negative }\end{array}$ & $\begin{array}{l}\text { Claiming common ground } \\
\text { Minimizing the Imposition }\end{array}$ & \\
\hline Conversational Strategy & $\begin{array}{l}\text { Hinting } \\
\text { Persuasive }\end{array}$ & $\begin{array}{l}\text { Simile } \\
\text { Justification }\end{array}$ & \\
\hline
\end{tabular}

\section{Text (3)}

" Therefore I tell you, do not worry about your life, what you will eat or drink, or about your body, what you will wear. Isn't there more to life than food and more to the body than clothing? Look at the birds in the sky. They do not sow, or reap, or gather into barns, yet your heavenly Father feeds them. Aren't you more valuable than they are ?".(Matthew, 6:2527).

The current text implies a warning speech act in which Christ (y of worldly life and abandoning the heavenly world where the eternal comfort and happiness are. Moreover, it implies an order by

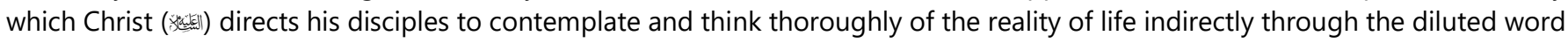
'look'. Equally important, persuasion is doubled by the style of pleasure by the verb 'look' since it calls for the evocation of things as if they were present actually. The mitigating effects are presented syntactically by using the ' rhetorical questions ' and negation. The rhetorical questions are used to decrease the directive's weight of imposition, that is, 'you, (my disciples ) should be satisfied with what your God ( (je endows you and do not be worry about tomorrow since you will be the light that guides people rightly through your good deeds. Additionally, these questions present a positive politeness strategy by intensifying interest to the hearers that their needs and interests are the concern of God ( ( the hearer's negative face through the speaker's wish to refrain from being impositive overly, and wrapping the sentiment in a negative sentence that is, you are more valuable than birds which do not sow, rap, and gather into barns, so you must have strong

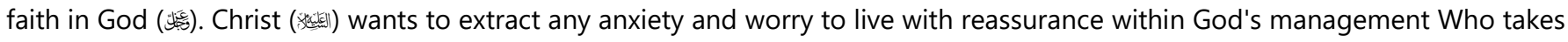
care of everyone and everything even birds. 
Table (3) Pragmatic Analysis of Text (3)

\begin{tabular}{|l|l|l|l|}
\hline \multicolumn{3}{|c|}{ Pragmatic Analysis } \\
\hline Speech Act & $\begin{array}{l}\text { Strategy } \\
\text { Type } \\
\text { Warning }\end{array}$ & $\begin{array}{l}\text { Direct } \\
\text { Beware of excessive indulging } \\
\text { in the pleasures of life. }\end{array}$ \\
\hline Diexis & Person & $\begin{array}{l}\text { Second Person } \\
\text { Plural }\end{array}$ & \\
\hline Politeness Strategy & Positive & $\begin{array}{l}\text { Intensify Interest to } \\
\text { Hearers } \\
\text { Minimizing the } \\
\text { Imposition }\end{array}$ & \\
& Negative & $\begin{array}{l}\text { The image of } \\
\text { Birds } \\
\text { Questioning }\end{array}$ & \\
\hline Conversational Strategy & Hinting & & \\
& Persuasive & & \\
& & & \\
\hline
\end{tabular}

\subsubsection{Pragmatic Analysis of Mitigation in Prophetic Traditions}

Text (4)

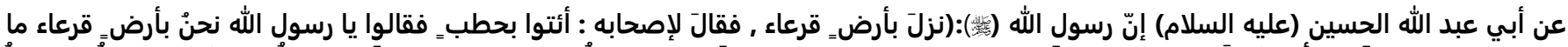

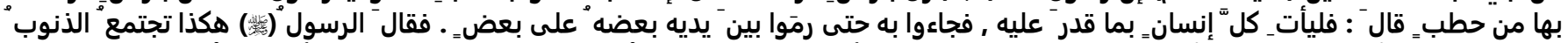

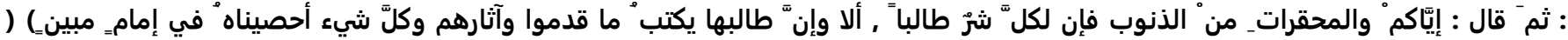
الكليني :جال: :288:

[ Abi Abdullah al-Hussain (peace be upon him) said: The Messenger of Allah (Allah's blessing and peace be upon him and his family) camped in a barren land, and he said to his companions, bring in firewood? They said, O, Messenger of Allah, we are in a barren land with no firewood, then he said, will every man bring in what he can. They return back and throw firewood before him one another together. There the Messenger of Allah (Allah's blessing and peace be upon him and his family) said: in this way the sins gather together, then he said: beware of the little sins, that are regarded as insignificant because every evil there will be a pursuer. Certainly, its pursuer will record that which they send before and that which they leave behind, and of all things have We taken account in a clear Book (of evidence)".]

This text starts with a ' drama ' with all its required elements, like the characters ( prophet (藏) and his followers ), the setting (the desert ), and the actions (bringing wood). It is a parable with a dramatic storyline approach ( قصة تمثيلية ذو مقاربة درامية (ق) This stylistic way is a representation of hinting strategy through which the speaker departs the direct and harsh way in various speech acts such as warning, threatening, criticism, and other ones which have negative effects on the listener's part. Then, the dramatic style is followed by a direct speech act of ' warning ', that is, prophet (籍) warns his followers of committing the small sins because they lead to the big ones. The harshness of this direct warning is mitigated and reduced by the preceding naive and simple way.

يكتب مُ قدموا وآثارهم وكلَّ شيء أحصيناه ( The explanation that follows the warning act is exploited to justify its danger and the verse is an indication of a persuasive strategy to make the text more effective and persuasive through its intertextuality. Consequently, the whole drama and the explanation are employed to make the warning less imposed and harsh on the hearers' part. 
Table (4) Analysis of Text (4)

\begin{tabular}{|l|l|l|l|}
\hline \multicolumn{3}{|c|}{ Pragmatic Analysis } \\
\hline $\begin{array}{l}\text { Speech } \\
\text { Act }\end{array}$ & Strategy & Direct & \\
& Type & Warning & \\
\hline Deixis & Person & Second Person Plural & \\
\hline $\begin{array}{l}\text { Politeness } \\
\text { Strategy }\end{array}$ & Negative & Minimizing the Imposition & \\
\hline Conversational Strategy & Persuasive & Intertextuality & \\
\hline
\end{tabular}

Text (5)

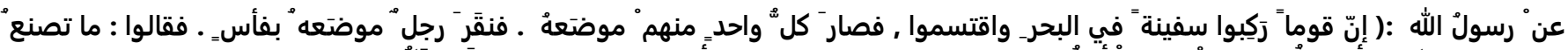

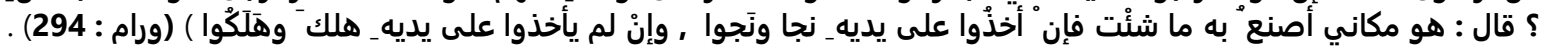

[The Messenger of Allah (Allah's blessing and peace be upon him and his family) said: "Some people boarded a boat in a sea. They divided its parts, so, for each one has its own part. A man with an axe made a hole in his part. They asked "what is wrong with you? He replied it is my own part and I do what I like. Now if they prevent him from doing so, they will save him and themselves, but if they leave him (to do what he wants), they will destroy him and themselves".]

The prophet (跑) warns indirectly his nation's members to be ignorant of their responsibilities toward their society and pay attention to all sins whether trivial or big. It is not enough to drop responsibility for the righteous ones to reform themselves and leave spoilers corrupt their society, but the righteous ones must do their best to stop spoilers by various means. Since the sins have a dangerous effect on the whole society and each sin has its own effects inside families and society, it is supposed to struggle against these sins.

In this tradition Prophet Muhammed (紧) mentions such sins by an accurate ' simile' in a form of the parable with a narrative character (تشبيه تمثيلي ذو طابع قصصي) to motivate Muslim's attention toward their responsibilities. Thus, the kingdom and its people are like a ship and its riders, so each one in the kingdom must respect it and takes care of others' rights, and do not commit deeds that spoil the society. On the other hand, each one must be aware of his responsibility against who misuses his individual freedom, and as the result, he commits dangerous sins that destroy the whole society.

The word ' نقر ' (hammering) is a symbol of ' simple sins ' since hammering causes a hole. Whenever hammering is increased, the holes will be big, and as a result, the ship will sink. The directive speech act of warning is mitigated by an image of simile to clarify

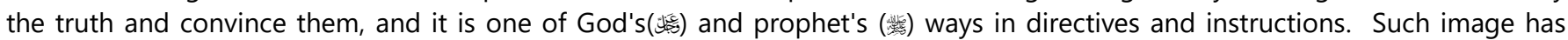
persuasive dimensions that contribute to a large extent in luring the recipients and directing them toward the inevitable result that leaving the promotion of virtue and prevention of vice is a great sin that has its dangerous impacts on the whole society. Importantly speaking, this image and the use of the third person plural pronoun which is implied in the attached pronoun ' 'الجماعة' (they) in the word ' نجوا' minimize the impact of the warning since it indicates claiming common ground, that is the guilty person and the others are one group. 
Table (5) Analysis of Text (5)

\begin{tabular}{|l|l|l|l|}
\hline \multicolumn{2}{|l|}{ Pragmatic Analysis } & \\
\hline Speech Act & $\begin{array}{l}\text { Strategy } \\
\text { Type } \\
\text { Intended Act }\end{array}$ & $\begin{array}{l}\text { Indirect } \\
\text { Assertive(Affirmation) } \\
\text { Warning }\end{array}$ & $\begin{array}{l}\text { Do not let the } \\
\text { spoilers corrupt the } \\
\text { society }\end{array}$ \\
& & & \\
\hline Diexis & Person & Third Person Singular and Plural & \\
\hline Soliteness Strategy & Positive & Claiming Common Ground & \\
\hline
\end{tabular}

Text (6)

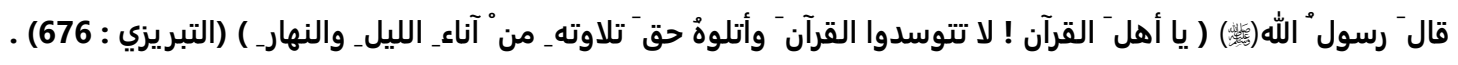

[The Messenger of Allah (Allah's blessing and peace be upon him) said:" O people of Quran, do not make the Quran a pillow, but recite it as it deserves to be recited during the night and the day."]

This test involves two main directive speech acts: warning and order. To produce mitigating effects, the two speech acts are preceded by the vocative construction 'يا أهل' القرآن' ( O the followers of Quran) which refers to esteem and high status of the person (s) who is (are ) called. So, it intensifies the prophet's(鷀) interest to the hearers. It is known that the particle ' is used to call the distanced person (s), but is sometimes used to call the one (s) who is (are) closed to indicate esteem and respect. This is one function of mitigation. Thus, this particle in this tradition is used to esteem the Quran reader. The negative effect of these two speech acts is also mitigated by the metaphorical expression ' لا تتوسدوا ' (do not make the Quran as a pillow ) which refers to lazing and disregarding. So, instead of using a direct warning 'لا تتكاسلوا أو لا تتغافلوا' ', (do not be lazy or do not be ignorant ), the prophet (慈) uses metaphors as a hinting strategy.

Table (6) analysis of Text (6)

\begin{tabular}{|c|c|c|c|}
\hline \multicolumn{4}{|c|}{ Pragmatic Analysis } \\
\hline Speech Act & $\begin{array}{l}\text { - Strategy } \\
\text { Type } \\
\text {-Strategy } \\
\text { Type }\end{array}$ & $\begin{array}{l}\text { Direct } \\
\text { Warning } \\
\text { Direct } \\
\text { Order }\end{array}$ & أتلوهُ حتوسدوا القرآن تلاوتهـ منْ آناء الليل والنهار \\
\hline Deixix & Person & $\begin{array}{l}\text { Second Person } \\
\text { Plural }\end{array}$ & \\
\hline
\end{tabular}




\begin{tabular}{|l|l|l|l|}
\hline Politeness Strategy & Positive & $\begin{array}{l}\text { Intensify Interest to } \\
\text { Hearers }\end{array}$ & \\
\hline $\begin{array}{l}\text { Conversational } \\
\text { Strategy }\end{array}$ & Hinting & & \\
\hline
\end{tabular}

\section{Results of Analysis}

Table (7) and Figure (7) below show that the most prominent speech acts utilized in biblical texts are directives especially, advising (50\%) whereas warning and ordering score the same percentage (7\%). Assertiveness (35\%) is employed to secondary functions like justification and explanation rather than performing. This result emphasizes the directive and exhorting nature of the religious discourse on one hand and the interest of such discourse in ' advising' because it is characterized with mildness rather than 'ordering ' which is identified with harshness. Negative and positive politeness strategies score the same percentage (50\%). This implies that the both strategies have an important role in mitigating the burden of the imposition of directives. The second person plural pronoun 'you' is the only person deixis used in the present data (100\%). This result can be justified with the view that this pronoun gives a sense of generality on one hand and makes the hearers feel that their needs are the concern of the legitimate text. Regarding conversational strategies, the three types: hinting, persuasive, and solidarity are used with the percentage (33\%,

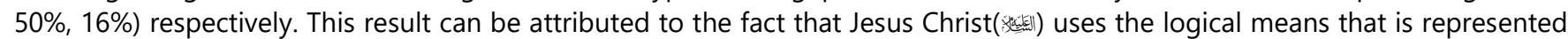
by argumentative and persuasive strategy as well as emotional means which is represented by hinting and solidarity strategies to stimulate the hearers and direct them to the desired goal according to the context in which the speech is uttered.

Table (7) Results of Pragmatic Analysis of Biblical Texts

\begin{tabular}{|c|c|c|c|c|c|c|c|c|c|c|c|}
\hline \multirow[t]{2}{*}{ No. } & \multicolumn{4}{|c|}{ Speech Act } & \multicolumn{2}{|c|}{$\begin{array}{l}\text { Politeness } \\
\text { Strategies }\end{array}$} & \multicolumn{2}{|c|}{ Person Deixis } & \multicolumn{3}{|c|}{$\begin{array}{c}\text { Pragmatic-conversational } \\
\text { Strategies }\end{array}$} \\
\hline & $\frac{\grave{d}}{\frac{0}{0}}$ & $\frac{\stackrel{0}{3}}{\frac{0}{2}}$ & $\begin{array}{l}\text { 을 } \\
\frac{5}{5} \\
\frac{\pi}{3}\end{array}$ & 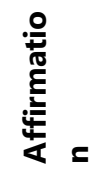 & 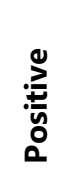 & 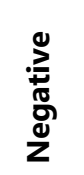 & 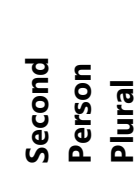 & 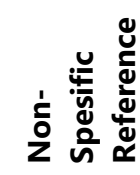 & 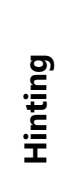 & 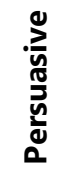 & $\begin{array}{l}\frac{7}{2} \\
\frac{\pi}{0} \\
\frac{0}{0} \\
\text { i }\end{array}$ \\
\hline Fre. & 1 & 7 & 1 & 5 & 3 & 3 & 8 & 0 & 2 & 3 & 1 \\
\hline Per. & $7 \%$ & $50 \%$ & $7 \%$ & $35 \%$ & $50 \%$ & $50 \%$ & $100 \%$ & $0 \%$ & $33 \%$ & $50 \%$ & $16 \%$ \\
\hline
\end{tabular}

As far as the prophetic traditions are concerned, ordering and warning score the same percentage (.37\%). Assertiveness (25\%) is used to mitigate these directives by illustrating or justifying the previous or following acts. This result also confirms the guiding and exhorting nature of the religious discourse. Both positive and negative polite strategies score the same percentage (50\%). This result is in line with the biblical texts. Second-person plural 'أنتم' (you) is wider employed (75\%) than the other person deixis to protect the hearers' negative face whereas non -specific reference is used with the percentage (25\%). Concerning conversational strategies, the hinting and persuasive score the percentage (66\% v.33\%) whereas solidarity strategy has no percentage since it is not used in the current data.

Table (8) Results of Pragmatic Analysis of Arabic Texts

\begin{tabular}{|c|c|c|c|c|c|c|c|c|c|c|c|}
\hline \multirow[t]{2}{*}{ No. } & \multicolumn{4}{|c|}{ Speech Act } & \multicolumn{2}{|c|}{$\begin{array}{l}\text { Politeness } \\
\text { Strategies }\end{array}$} & \multicolumn{2}{|c|}{ Person Deixis } & \multicolumn{3}{|c|}{$\begin{array}{l}\text { Pragmatic - } \\
\text { conversational Strategies }\end{array}$} \\
\hline & $\frac{\grave{0}}{\mathrm{0}}$ & $\frac{0}{3}$ & $\underbrace{}_{\substack{\frac{0}{5} \\
\frac{\pi}{3}}}$ & 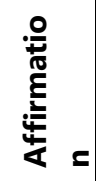 & $\frac{0}{: \frac{0}{n}}$ & 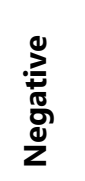 & 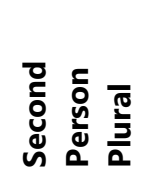 & 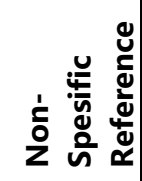 & 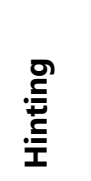 & 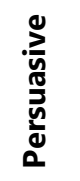 & 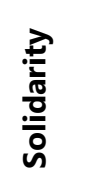 \\
\hline Fre. & 3 & 0 & 3 & 2 & 2 & 2 & 3 & 1 & 2 & 1 & 0 \\
\hline Per. & $\begin{array}{l}37 \\
\%\end{array}$ & $0 \%$ & $37 \%$ & $25 \%$ & $50 \%$ & $50 \%$ & $75 \%$ & $25 \%$ & $66 \%$ & $33 \%$ & $0 \%$ \\
\hline
\end{tabular}




\section{Conclusion}

The following conclusions can be drawn from the analysis of the present data:

1- Both biblical and prophetic traditions show variations in using directives. This result fully validates the first hypothesis that states "biblical verses and prophetic traditions show variations in the use of directive speech act".

2- Biblical texts widely use advising whereas the other types of directives, such as ordering and warning, score the same percentage in the prophetic traditions.

3- Negative and positive politeness strategies in both texts score the same percentage (50\%). This result is a fully validated hypothesis (2) "both positive and negative politeness strategies are employed in religious discourse".

4- Both biblical and prophetic texts extensively use second person plural pronoun (100\% v. $75 \%$ ) to mitigate the unwelcome effects of directives since this pronoun gives a sense of generality. This result partially invalidates the third hypothesis that states" non-specific reference and second person plural as deictic expressions are supposed to be used widely in this discourse since they give a sense of generality and non-specificity".

5- The three types of conversational strategies are utilized in biblical texts. This indicates the diversity of the strategies that are employed in religious discourse to achieve the desired goals whereas hinting strategy scores the highest percentage (66\%) in prophetic traditions. This partially invalidates hypothesis (4)" hinting strategy is employed highly in religious discourse because it indicates indirectness".

\section{English References}

[1] Al-hindawi, Fareed, H. \& Al- khazaali, M. (2011). Towards a Model of Local Pragmatic Coherence. Journal of the Human Sciences. College of Education for the Humanties. University of Babylon.

[2] Austin, J. L. (1962). How to Do Things with Words.Oxford:Clarendon.

[3] Bally, C. (1970). Traite ' de StylistiqueFrancaise. Gene've: Librerie del universite.

[4] Boubendir, F. (2012). Linguistic Politeness in English and Arabic And Its Implications for Translation. A Thesis of the Degree of Master. The University of Petra.

[5] Brown, P. and Levinson, S. (1987). Politeness: Some Universals in Language Use. Cambridge: Cambridge University Press.

[6] Caffi,C . (2007). Mitigation. Amsterdam: Elsevier.

[7] Edmondson, W. (1981). Spoken Discourse: A Model for Analysis. London: Longman.

[8] Fraser, B. (1980). " Conversational Mitigation ". Journal of Pragmatics, 4, pp.341-350.

[9] Goffman, E. (1967). Interaction Rituals: Essays on Face- to Face Behaviour. New York: Doubleday Anchor Books.

[10] Grice, P. (1975) Logic and Conversation. In: Peter Cole and Jerry L. Morgan (eds.), Syntax and Semantics 3: Speech Acts, 41-58. New York: Academic Press

[11] Marmaridou, S. (2000). Pragmatic Meaning and Cognition. Amsterdam and Philadelphia: John Benjamin's.

[12] Prince, F., Frader, J. \& Bosk, C. (1982). ' On Hedging in Physician -Physician Discourse'. In Dipietro R. J. (ed.) Linguistics and the Professions: Proceedings of the second Annual Delaware Symposium on Language Studies. Norwood, NJ: Ablex. 83-97.

[13] Searle, J., Kiefer, F. \& Bierwish, M. (1980). Speech Act Theory and Pragmatics. Dordrecht: D. Reidel Publishing.

[14] The King James Version of the Holy Bible (PDF Version). (2004). Downloaded from: http://www.davince.com/bible.

\section{Arabic References}

[1] Al-Tabrizi, M. (1985). Mushkat Al massabih, Birut: Al Maktab Al Islami

[2] Taghzawi, Y. (2014). Al wadhiff Al laghwayia wa Strategic A I tawassil Al laghawi fi Nadhareit Al nahu al Wadheefi Arbid: Alam al kutub Al hadith.

[3] Al-Jami, N. (2003). Sharh Kyat ibin alhajib. Cairo: Dar alaffaq al arabyia

[4] Al-gelatin, I. (2012). Al murssal bain Al ellqaa' wa Asaleeb aleknaa'. Algeria: Ibin Khaldoon University

[5] Hassan, T. (2006) Arabic Language: Its meaning and Construction. Cairo: Alam alkutub.

[6] Al-sakaki, A. (1983) Muftah Aluloom. Birut: Dar alkutub al elmyia.

[7] Al-Shahari, A. (2004). Strategic al khitab: Muqarabh Laghawyia Tadawilyia. Birut: Dar al kataab al jaded

[8] Alkulaini, M. (1934). Al Kaffi, part 2. Tahran: Dar al kutub al Islamyia.

[9] Al-maliki, M. A. (1987). Muhammed (peace be upon him): Al insaan al kamil. Jida: Dar al shurook

[10] Hajar, M. (2013). Al khitab al hijaji: Anwahu, wa Khasa'sahu. Algeria: Al ekhtilaf Manshuraat.

[11] Warram A. (2003). Tanbeeh al khawatar wa Nazhat al Nawadhar. Karbala: Al atabh Al Husseinyia Al muqadasa. 